DOI: 10.15393/j9.art.2019.6442

УДК 801.161.1.09"1917/1992"

О. А. Бердникова

Воронежский государственный университет (Воронеж, Российская Федерация)

olberd@mail.ru

\title{
Поэтика адресованных жанров в творчестве И. А. Бунина
}

Аннотация. Статья посвящена исследованию адресации как коммуникативного художественного феномена в поэтическом творчестве И. А. Бунина, выявлению жанровых, тематических и стилевых особенностей адресации. В его поэзии сохраняется установка на следование классической традиции и сохранение адресованных стихотворений в их жанровой определенности, причем доминирует «вневременная адресация». Адресация обнаруживается в заголовочном комплексе и жанре произведений. Эпитафия и эпиталама сохраняют у Бунина жанрообразующую функцию адресованных жанров. Наиболее модифицированные формы связаны с жанрами посвящений и посланий. Свойственная эпохе тенденция к циклизации приводит к появлению в поэзии Бунина «скрытых» именных циклов (надсоновский, бальмонтовский). Однако имя адресата является основным и единственным объединяющим началом: сами стихотворения-посвящения почти не содержат цитат, аллюзий и иных знаков адресата, поэтому снятие посвящений лишают стихотворения всяких примет адресованного жанра. Наиболее частотны своеобразные адресованные жанры, объединенные тематикой памяти и парадигмой «смерть поэта», преобразуемой у Бунина в понятие «могила / гробница поэта» / легендарной личности. Появляется особый жанр - эпитафическое дружеское послание, представляющее панегирический тип адресации и позволившее поэту осмыслить категорию «прапамяти». Диалогизация текста часто имеет характер «автоадресации». В меньшей степени представлена ироническая адресация, направленная на полемику с доминирующей в поэзии модернистской эстетикой. Бунин вносит свой вклад в разработку новых художественных коммуникативных стратегий, формирующихся в поэзии ХХ в.

Ключевые слова: Бунин, поэзия, адресованные жанры, «скрытые» циклы, парадигма памяти, эпитафическое послание, панегирический тип адресации, новые художественные коммуникативные стратегии

Об авторе: Бердникова Ольга Анатольевна - доктор филологических наук, профессор кафедры русской литературы XX и XXI веков, теории литературы и фольклора, Воронежский государственный университет (пл. Университетская, 1, г. Воронеж, Российская Федерация, 394018)

Дата поступления: 19.04.2019

Дата публикации: 18.10.2019

(C) О. А. Бердникова, 2019 
Для цитирования: Бердникова О. А. Поэтика адресованных жанров в творчестве И. А. Бунина // Проблемы исторической поэтики. -2019. T. 17. — № 4. - C. 215-241. DOI: 10.15393/j9.art.2019.6442

И ван Алексеевич Бунин как поэт занимает совершенно особое место в русской литературе XX в. Его поэзия, по времени совпавшая с Серебряным веком, во многих отношениях противостояла модернистским тенденциям этой эпохи. Впрочем, «меру» модернизма Бунина отмечали еще критики начала XX в. ${ }^{1}$ Но в культурном пространстве русского зарубежья его поэзия не была востребована из-за ее традиционности: «Как поэт он принадлежит девятнадцатому веку, но как прозаик он старший из писателей, открывающих в нашей литературе двадцатый век» [Вейдле: 431].

Лишь на рубеже XX-XXI вв. пришло осознание того, что его поэзия - уникальный художественный феномен, загадки которого начали разгадывать ученые нашего времени. Этому как нельзя более способствовало издание двухтомного собрания стихотворений И. А. Бунина в серии «Новая библиотека поэта» в 2014 г. ${ }^{2}$, актуализировавшее исследовательский и читательский интерес к его поэзии. Выверенные текстологические данные двухтомника уточняют, а часто и существенно изменяют представления о многих значимых текстах. К счастью, в подготовке двухтомника текстологическая работа была осуществлена «как технология», позволившая «выявить авторский текст, понять его грамматику, смысл», так пишет В. Н. Захаров о задачах современной текстологии, которую ученый считает «главной филологической дисциплиной» [Захаров: 221].

Адресация как одна из наиболее интересных и специфических форм выражения авторского сознания в лирическом творчестве во многих отношениях есть текстологическая проблема. Ее постановка и научное решение стали возможными в полной мере после появления академического собрания поэтических текстов Бунина. Теперь его поэзия может изучаться и оцениваться как художественная целостность в объеме произведений, опубликованных в разных прижизненных изданиях и не входивших в них черновых вариантов, 
переводов, незаконченных текстов. В научных комментариях зафиксировано изменение заголовков, уточнена датировка, даны критические оценки и необходимые биографические данные (см.: [Двинятина, 2014a, 2014b]).

В аспекте адресации поэзия Бунина практически не изучалась ${ }^{3}$. Целью данной статьи является выявление жанровых, тематических и стилевых особенностей адресации в поэтическом творчестве Бунина.

Литературоведческий аспект проблемы адресации, поставленной еще в трудах ученых, представляющих историческую поэтику, был актуализирован исследованиями современных теоретиков литературы: В. И. Тюпы, Л. Кихней, Е. В. Дмитриева, Т. С. Кругловой (см.: [Тюпа], [Кихней], [Дмитриев], [Круглова]). Уточняя идеи Ю. М. Лотмана о формах диалога в лирических текстах, Е. В. Дмитриев справедливо пишет об «общей памяти» у адресата (читательской аудитории) и адресанта (текста как такового), дифференциация которой происходит на уровне авторской установки. Отсюда «вытекает задача анализа прагматических стратегий автора и адресата поэтического произведения, стратегий, обусловленных эстетическими особенностями самого текста, имманентно ему присущих» [Дмитриев: 15-16].

В классической поэзии адресация играла, в первую очередь, жанрообразующую роль, формируя жанры оды, сатиры и послания. Новая - модернистская - поэзия начала XX в., наследуя богатую традицию, дает крайне разнообразный и необычный материал для изучения фактора адресации: наблюдается «расцвет адресованных жанров», особенно так называемых «кружковых» адресаций (Е. В. Дмитриев). «Жанр не исчезает и не обесценивается. Он как бы уходит в подтекст, поэтому его труднее распознать, нежели в предшествующую эпоху», каждый новый поэт «имеет возможность “манипуляции” жанровыми канонами, вступая с ними в “диалогические” отношения» [Кихней].

Адресованная лирика русского модернизма особенно интересна и значима в поэтологическом аспекте (см.: [Круглова]). В модернистских поэтических течениях ученые отмечают разнообразие диалогически ориентированных жанровых форм, 
но основными жанровыми модификациями оставались посвящение и послание. Так, в творчестве каждого отдельного поэта формировалось особое культурное пространство, структурированное разными типами адресатов - учителю, единомышленнику, оппоненту, абстрактному собеседнику, читателю.

На фоне «диалогичной» поэзии модернизма бунинская поэзия представляет собой явление «аскетичное», но тем более интересны и значимы произведения, имеющие адресатов. Обращения, вопросы, риторические фигуры, являющие приметами адресованных жанров, - достаточно распространенные грамматические формы в стихах Бунина. Поэт, следуя классической традиции, пишет стихотворения-посвящения в их четких жанровых признаках - с обозначенным в заголовочном комплексе адресатом: «Родине» (1898), «Матери» (1901, 1910), «Поэту» (1915).

С точки зрения адресации особенно любопытны бунинские стихотворения о родине. Первое из них, не содержащее примет адресации, — «Родина» (1896) - опубликовано в «Русском богатстве» в 1898 г. под заглавием «На севере», в других изданиях - «На родине», позже, в прижизненных сборниках, печаталось без названия, но все-таки оставлено автором для последующих изданий под заголовком «Родина» [Двинятина, 2014a: 468]. История поиска наиболее точного заглавия свидетельствует об осознании Буниным ответственности за столь значимую для русской традиции тему.

В стихотворении «Родина» (1896) изображен «угрюмый» зимний день: северный простор, названный «снежною пустыней», «мертвенно-свинцовое» небо, безграничные сосновые леса. Но пейзажную зарисовку, наводящую тоску, «смягчает» (не случайна эта бунинская метафора), «один туман молочносиний» как «чья-то кроткая печаль» $(1,174)$.

Адресованный жанр в стихотворении «Родине» (1898) позволяет поэту не просто смягчить, а усилить чувство любви и сострадания к «убогой» России: в первом четверостишии одически возвышенно звучит обращение «о родина». Некрасовская любовь к народной России ближе поэту, чем глумление и укоры обличителей пороков: 
«Они глумятся над тобою,

Они, о родина, корят

Тебя твоею простотою,

Убогим видом черных хат...» $(1,178)$.

Отсюда, столь презрительно сравнение обличителей со «спокойным и нахальным сыном», стыдящимся «усталой, робкой и печальной» матери-родины, сострадающей своим неблагодарным детям:

«Глядит с улыбкой состраданья

На ту, кто сотни вёрст брела

И для него, ко дню свиданья,

Последний грошик берегла» $(1,179)$.

Уже после революции, в эмиграции, Бунин пишет стихотворение «России» (1922), являющееся поэтическим переложением 136 псалма «На реках Вавилонских». Фактор адресации (не «Россия», а «России»; в 8 томе изданного в Берлине в 1934-1936 гг. собрания сочинений в 11 томах еще более определенно - «России Ленина» (см.: [Двинятина, 2014b: 463])) усиливал обличительный пафос авторского голоса, обращенного к Блуднице-России: «Блажен, кто раздробит о камень, / Твоих, Блудница, новых чад». Однако позже Бунин снимает заголовок «России», понимая «тщетность» («О, тщетной ненависти пламень!») сведения счетов с Родиной и возлагая миссию возмездия на «Господнее святое мщенье» $(2,188)$. С. Н. Морозов справедливо пишет о том, что во многих произведениях вплоть до 1922 г., который исследователь выделяет как итоговую дату одного из периодов его творчества, чувствуется «неутихающая боль писателя по потерянной Родине» [Морозов: 11].

Подобное сочетание адресованных и неадресованных жанровых модификаций наблюдается и в стихотворениях, посвященных матери. Стихотворение Бунина «Матери» («Я помню спальню и лампадку...», 1901; 19104) воссоздает ситуацию его раннего стихотворения «Мать» («И дни и ночи до утра...», 1893) - ночное бдение матери, качающей ребенка и ограждающей его от темных стихий мира.

В обоих текстах сделан акцент на голосе матери: в стихотворении 1893 г. «И, положив дитя к плечу, / Все напевала 
и ходила...» $(1,153)$ и в адресованном тексте «Я помню, помню голос твой!» $(1,244)$. Однако если в раннем стихотворении романтический пейзаж («в степи бураны бушевали», «...буран в порыве диком / Внезапным шквалом налетал») усиливает беспокойство и тревогу матери, то в адресованном стихотворении-воспоминании подчеркнуты исходившие от нее тепло и покой:

«Ты перекрестишь, поцелуешь, Напомнишь мне, что Он со мной, И верой в счастье очаруешь...

Я помню, помню голос твой!» $(1,245)$.

Образ матери как адресата бунинского стихотворения конкретизируется, прежде всего, биографическим контекстом: как известно, мать Бунина - Людмила Александровна Чубарова - была глубоко, «горячо», как говорил сам поэт, верующим человеком. И в стихотворении-посвящении подчеркнута ее кротость, трижды упомянута лампадка над детской кроваткой, ее крестящий (благословляющий) ребенка жест, традиционное для православных людей прощание-пожелание «Ангел-хранитель над тобой!». Однако риторический вопрос в финале: «Не ты ли ангелом была?» - не только конкретизирует, но и обобщает образ матери, декларирует ее архетипический статус. Возвращение Бунина в 1910 г. к стихотворению «Матери» (1901 г.) было вызвано болезнью, за которой последовала кончина Л. А. Чубаровой в 1910 г. в г. Ефремове. Автор примечания к новому двухтомнику ссылается на воспоминания В. Н. Муромцевой-Буниной о желании И. А. Бунина «порадовать мать» этим стихотворением, высоко оцененным критиками начала XX в. (см.: [Двинятина, 2014a: 495]).

Большое стихотворение «Мать» («На пути из Назарета...», 1912) в некоторых публикациях имело заголовок «На пути из Назарета». Оно написано белым стихом с необычной восьмистрочной строфой и посвящено Пресвятой Богородице $(2,84-87)$, что возводит тему матери на метафизический уровень. Окончательный авторский вариант стихотворения заканчивается обращением к Деве Марии («О, Мария, сладко сердцу / Вспоминать и поминать...»), объединяющим лирического героя с людьми в их глубоком и трепетном 
преклонении «пред любовью, / Галилейской нищетою / И сладчайшим словом: Мать» $(2,87)$.

Столь же интересен поэтологический ряд адресованных текстов: «Поэт» («Поэт печальный и суровый...», 1886), «Поэту» («Не разрешит твой ум тревожного сомненья...», 1887) и «Поэту» («В глубоких колодцах вода холодна...», 1915). Раннее адресованное стихотворение входит в так называемый «надсоновский» цикл, заявленный первым опубликованным стихотворением поэта «Над могилой С. Я. Надсона» (1887). Сохраненный в автографе стихотворения «Над могилой С. Я. Надсона» эпиграф с цитатой из стихотворения М. Ю. Лермонтова свидетельствует, что семнадцатилетний Бунин входит в литературу в русле одной из доминирующих тем русской поэтической традиции - «смерть поэта». Все стихотворения «надсоновского» цикла, варьируя надсоновские мотивы, вплетают «лепестки» в «надгробный лавровый венок» $(1,201)$ безвременно ушедшего и столь почитаемого юным Буниным С. Надсона. Не случаен в этом ряду и сугубо поэтологический посыл в стихотворении «Поэту» (1887).

В нем сохранены все внешние приметы послания-посвящения: звучат уверения «не будешь ты забыт», дважды повторены призывы «верь», обращения к толпе, которая должна понять «любовь и муки» умершего поэта, его «песни скорбные», несущие «братское сожаленье», «правду любви» и «грусть неземную» $(2,206-207)$. Подобный набор романтических штампов, вероятно, и послужил причиной того, что все тексты «надсоновского» цикла, появившиеся спустя год после смерти Надсона в журнале «Родина», не включались Буниным в авторские издания.

Между тем столь же романтическое, едва ли не первое его стихотворение «Поэт» (1886), содержащее в самом тексте все приметы адресации, но посвященное теме нищеты истинного поэта, оставлено Буниным для последующих изданий:

«Когда ж, измученный скорбями, Забыв бесплодный, тяжкий труд, Умрешь ты с голоду, - цветами Могильный крест твой перевьют!» $(1,97)$. 
Заглавие позднего стихотворения «Поэту» (1915) создает «эффект ожидания <...> как такой фактор художественного впечатления, который ставит читателя в позицию солидарности с напряжением творческой интенции лирического героя» [Тюпа: 106]. Эта особенность, отмеченная В. Тюпой при разборе стихотворения А. Ахматовой «Муза», содержит важный теоретический вывод, точно обозначающий общую для многих авторов ситуацию адресации / самоадресации поэта поэту. Однако это бунинское стихотворение как бы обманывает ожидания читателя: здесь нет традиционных пожеланий (указаний) поэту. В сюжетах двух притч в аллегорической форме Бунин размышляет о том, как истинный поэт ищет единственные - «чистые» и «бесценные» - слова. Стихотворение получило высокую оценку критиков; оно особенно восхитило И. С. Шмелева, назвавшего его шедевром ${ }^{5}$. Здесь вполне прозрачен евангельский источник образов, в которых метафорически представлен поэт. В первой части - это «нерадивый» и «добрый» пастухи, ищущие воду, чтобы напоить пасомых: «В глубоких колодцах вода холодна, / И чем холоднее, тем чище она» $(2,107)$. Во второй части - послушный «раб», ищущий «бесценный алмаз, оброненный в ночи» $(2,108)$. Они объединены идеей трудности жизненного предназначения и исполнения возложенной на человека миссии. В последней строке стихотворения звучит характерный для притчи нравоучительный вывод, содержащий единственное в этом тексте обращение к адресату: «И знай: он с алмазом вернется к чертогам» $(2,108)$. Как поэт своей эпохи, Бунин был озабочен поиском новых образных средств в поэзии, он искал их в бесценных богатствах классической парадигмы русской культуры и духовности.

Особую группу формируют посвящения-послания также с «вневременной адресацией» (Е. В. Дмитриев), но представляющие сугубо авторский выбор адресатов: «Ваятелю» (1904), «Мистику» (1906), «Мудрым» (1906) - и объединенные полемическим и декларативно-дидактическим пафосом, направленным против символистской художнической элиты.

Опубликованное в 1904 г. стихотворение «Ваятелю» Бунин позже не включал в свои собрания сочинений, видимо, из-за 
его излишней декларативности. Обращение к адресату дано только в первых двух строках стихотворения: «Изваяй красоту из холодного белого мрамора, / Изваяй нам мечту, к дерзновенному счастью призыв!» Остальные шесть строк посвящены изображению рассвета, гор, лазурного неба, «белого города», «брызг солнца» и «синего залива», то есть создается идеальный южный пейзаж, вдохновляющий ваятеля, под резцом которого «Красота восстает!» $(2,237)$.

В противовес эпатирующим заявлениям поэтов-символистов о «новой красоте», ради которой художник готов был «перейти все границы» и «преступить все черты», Бунин показывает художника-творца «соработником» природной, естественной красоты мира, так как только такая красота может рождать в человеке «любовь и радость бытия».

«Мудрым» и «Мистику» (в первой публикации «Мистикам») примечательны как тексты, в которых адресация заявлена только в заглавиях, между тем сами произведения лишены примет адресованных жанров. Адресатом в них является не единомышленник, а оппонент автора, что у Бунина получает приметы своего рода пародийной, иронической адресации.

Стихотворение «Мудрым» печаталось в составе цикла «Ислам» с подзаголовком «из книги “Восток”» (см.: [Двинятина, 2014b: 347]) и вызвано «первой поездкой Бунина в Константинополь в апреле 1903 года» (см.: [Двинятина, 2014a: 509]). Здесь ирония открыто заявлена Буниным: мудрым он называет «труса», который, в отличие от героя, давшего врагу «безумный отпор», но погибшего «в неравной схватке», «лелеет месть тайком»: «О, да, он мудр! Но сердце в нем чуть тлеет: / Как огонек под кизяком» $(2,11)$. Цикл «Ислам» получил неоднозначные оценки критиков: похвалу Ф. Д. Батюшкова и критические замечания Н. Абрамовича, который в рецензии на Собрание сочинений (1906) заметил, что стихотворения, входившие в «Ислам» «слабее» других стихотворений Бунина (см.: [Двинятина, 2014a: 509]).

Стихотворение «Мистику» (1906), напечатанное в «Русской мысли», при жизни Бунина неоднократно переиздавалось в Собраниях сочинений, при этом в шеститомном Полном 
собрании сочинений 1915 г. убиралось заглавие и пятая, заключительная строфа, содержащая итоговую сентенцию. Полемичный аспект стихотворения акцентирован тем, что героем является ребенок, вошедший ночью в «холодный зал, луною освещенный» и испугавшийся сумрака и теней. Темноте и сумрачному блеску зала противопоставлены ясность неба, свет Луны, а в пятой, заключительной, строфе и содержится обращенный к мистику дидактический вывод:

«Теперь давно мистического храма

Мне жалок темный бред:

Когда идешь над бездной - надо прямо

Смотреть в лазурь и свет» $(2,13)$.

В этом стихотворении читатель Серебряного века легко узнавал набор символистских образов: зал с высокими окнами, лунный свет, тени, «снежная пыль», дымящийся «ладан сумрака", дважды повторенное сравнение с алтарем, а также лазурь, свет. Но мир реальный и отраженный в окнах, серебре и «вощеном» блеске пола не совпадают, более того, вызывают совершенно противоположные переживания: отраженный мир пугает, а реальный радует - «и страх исчез». Ведь в природном мире «небо ясно», та же таинственная Луна «чиста, светла», поэтому ночная «мгла» вовсе не страшна. Автор призывает мистически настроенных читателей той эпохи доверять реальному бытию, а не его искаженному отражению в «образном мире» нового искусства.

Вместе с тем, как поэт XX в., Бунин так же, как и его современники, вступает с традиционными жанрами в «диалогические отношения». Так, в стихотворении «Сатана Богу» (1903-1906), впервые опубликованном в составе цикла «Ислам» (см.: [Двинятина, 2014b: 345]), поэт обращается к одному из сюжетов Корана, цитата из которого содержится в эпиграфе, где некий мятежный «огненный ангел» Эблис отказался поклониться Адаму: «Я - из огня, Адам - из мертвой глины, / И Ты велишь мне пред Адамом пасть!» $(2,10)$. В основе вызова злого гения Богу лежит противопоставление смирению «живой страсти» - происходит как бы оживление сотворенного из «мертвой глины» Адама: 
«...Смотри: уж твой Адам

Охвачен мной! Я выжгу эту глину,

Я, как гончар, закал и звук ей дам» $(2,10)$.

В известной мере здесь Бунин отдает дань одной из универсалий Серебряного века - идее «живой жизни», призванной «реабилитировать» естественные страсти человека. Это уникальный пример своего рода ролевой адресации - в духе модных идей и форм модернистской эпохи.

Именные стихотворения-посвящения - «(Посв. Г. А. Лукину)» (1889), «(В. В. П.)» (1890), «(Ю. А. Бунину)» (1891) - обращены к близким ему людям: другу семьи, хвалившему самые первые опыты юного поэта, возлюбленной - Варваре Владимировне Пащенко - и брату Юлию. Посвященные разным людям - родным, современникам и уже ушедшим из жизни, - они объединены гражданским пафосом. Адресаты некоторых стихотворений, именованные «друг мой», «милый друг мой» предполагают любого человека, для которого важен выбор цели и смысла жизненного пути, заключающегося в служении родине и ближним. Народнические настроения молодого Бунина переплетаются с любовными переживаниями и поэтической рефлексией, и адресованные жанры оказались в этом отношении наиболее адекватно выражающими содержательный посыл автора.

Единственная публикация в «Орловском вестнике» в 1890 г. стихотворения, посвященного годовщине смерти М. Е. Салтыкова («Памяти М. Е. Салтыкова», 1889), представляется тем не менее интересным фактом бунинской адресации. Русский писатель-сатирик памятен Бунину как «великий гражданин», для которого «дороги и святы / Интересы родины своей» $(2,212)$. Сочувствуя гражданской позиции Салтыкова-Щедрина, девятнадцатилетний Бунин с наивным юношеским пылом защищает писателя от упреков недоброжелателей и поучительно заявляет, обращаясь к нему: «Верь, что нет - без злобы и печали — / И любви, глубокой и святой» $(2,212)$.

В ряду ранних стихотворений-посвящений в поэзии Бунина явно просматривается бальмонтовский цикл, причем имя К. Бальмонта в первых публикациях было заявлено в заголовочном комплексе. Выделение его имени из ряда поэтов- 
символистов в высшей степени интересно. В статье «Заметки к теме “И. Бунин и К. Бальмонт” П. В. Куприяновский впервые описал историю их знакомства, дружбы и охлаждения отношений [Куприяновский: 50]. Он же находит стихотворения, в первых публикациях посвященные К. Бальмонту: под заголовком «Посвящается К. Д. Бальмонту» («Ни песен, ни солнца... О сердце мое!», 1895) и «Ночная вьюга» («Когда на темный город сходит...») (1895) с пометой «К. Д. Бальмонту», попавшее в сборник «Листопад» (1901) и оставшееся в основном корпусе бунинских текстов, но без посвящения.

Более зрелое стихотворение «Посвящ. К. Д. Бальмонту» (1899), впервые появившееся в журнале «Север» в 1899 г. и опубликованное в двухтомнике 2014 г., поэт не включал ни в одно из прижизненных изданий. Между тем именно оно - классический пример стихотворения-посвящения, где очевидна изящная стилизация - воссоздание ритмики, напевности стихотворений «поэта с утренней душой» и его настроений, вполне узнаваемы его мотивы и образы. Обозначенное в первой строке согласие с настроениями Бальмонта («Да, томит наше сердце предчувствие странное») влечет за собой отрицание основного и самого известного его поэтического тезиса «Будем как Солнце»: «Солнца нам не видать! И тоска одиночества, / Бесконечная грусть - наш удел вековой» $(2,230)$. В стихотворениях Бунина 1899 г. (отметим, что это самый непоэтичный год в его творчестве) заметны настроение тоски, грусти и одиночества, вызванные любовными переживаниями. Более того, два из опубликованных стихотворений 1899 г. вдохновили известных русских композиторов на создание романсов (см.: [Двинятина, 2014a: 472-473]), а стихотворение «Нынче ночью кто-то долго пел» уже в 1921 г., спустя два десятилетия после его написания, получило в письме к И. А. Бунину восторженный отклик К. Бальмонта. То есть своего рода бальмонтовский «дух» достаточно заметен в стихотворениях 1899 г.

Вместе с тем выключение или снятие посвящений К. Бальмонту из основного корпуса поэтических произведений самим Буниным вполне объяснимо. Даже жанровые законы стихотворения-посвящения не «примирили» его с чуждой образностью и чуждыми сентенциями, не вписывавшимися в контекстный ряд его стихотворений. В. Брюсов проницательно 
писал, что «Бунин противоположен Бальмонту» и по темам и по «стиху» [Брюсов, 2001: 267].

Однако с именем К. Бальмонта связано еще одно адресованное стихотворение Бунина «Эпиталама» (1901), опубликованное в «Журнале для всех» в 1901 г. «с посвящением К. Бальмонту» (см.: [Двинятина, 2014a: 493]). В поздних изданиях посвящение было снято, но само стихотворение оставлено в корпусе основных текстов. Оно процитировано в «Силуэтах русских писателей» Ю. Айхенвальдом, отметившим типичное для Бунина сближение «свадьбы и смерти» [Айхенвальд: 421]. Комментаторы усматривают связь эпиталамы Бунина со стихотворением К. Бальмонта «Венчание» (1899) (см.: [Двинятина, 2014a: 493]). Однако различие между этими двумя текстами, действительно имеющими сходные мотивы, определяется именно ярко выраженными у Бунина адресованными признаками эпиталамы как торжественного и жизнеутверждающего жанра.

Бунин описывает обряд венчания в старом храме под ночной шум вьюги, вызывая аллюзию на пушкинскую «Метель» и, согласно законам жанра, воспевает юность и непорочность невесты, обращаясь к новобрачной и призывая ее быть любимой, сохранить «убор венчальный» как залог «безначального» и «непорочного света любви», противостоящего краткости и печали жизни, которую всегда стережет близость смерти. Спустя год появится «Эпитафия», словно трагическое продолжение «Эпиталамы»: «Я девушкой, невестой умерла...» $(1,246)$.

Таким образом, адресация в бальмонтовском «цикле» базируется не на жанровых признаках стихотворения-посвящения, а на имени адресата, которое и является основным и единственным объединяющим началом. Снятие посвящения в заголовочном комплексе лишает эти произведения какихлибо примет адресованного жанра.

Категория памяти - доминанта художественного сознания Бунина, запрограммировавшая в его поэзии три разных адресованных жанровых модификации. Память, запечатленная в слове, которому, по Бунину, «жизнь дана», стала предметом изображения в традиционном адресованном жанре эпитафии, представленном тремя стихотворениями: «Надпись на могильной плите» (1901), «Эпитафия» (1902) и одноименное стихотворение 1917 г. 
Стихотворение «Надпись на могильной плите» (1901) написано по жанровым канонам эпитафии, где адресат и адресант меняются местами: адресант представлен звучащим «из тьмы веков» словом. Но слова, написанные на могильной плите, обращены не к ныне живущим людям, а к Богу:

«Несть, Господи, грехов и злодеяний

Превыше милосердья Твоего!

Рабу земли и суетных желаний

Прости грехи и горести его» $(1,228)$.

Это и покаянная молитва, и исповедь человека, выполнившего Божьи заповеди - любви к ближнему и прощения врагов:

«Я не питал змею вражды на брата,

Я все простил, по слову Твоему» $(1,228)$.

Именно статус духовно просветленного человека позволяет ему «благовествовать земле» «Глаголы Незакатной Красоты» $(1,229)$, то есть вечные слова покаяния за греховную земную жизнь и Божьего благословения земной жизни - «происходит преодоление “загробного молчания” Словом» [Кихней]. Такую оценку, данную Л. Г. Кихней эпитафической лирике А. Ахматовой, в определенной мере можно считать жанровым критерием эпитафии в целом. В бунинской «надписи» на могильной плите четко выражена ориентация на высокую стилистику псалма и молитвы. Вовсе не случайно Бунин, не боявшийся повторять заглавия своих стихотворений, в данном случае называет стихотворение «Надписью» на могильной плите, дает синоним к слову «эпитафия», понимая жанровое и смысловое несовпадение понятий. Это несовпадение особенно очевидно в сравнении «Надписи» с двумя другими бунинскими эпитафиями: в них речь идет о земной, «закатной» красоте, и адресат, согласно канонам жанра, обращается к живым.

В обеих «Эпитафиях» Бунина сюжетным стержнем становится смерть юной девушки, то есть по сути продолжает осмысляться столь значимая для поэта тема красоты. В раннем стихотворении 1902 г. (первоначальное название «На кладбище» с подзаголовком «Сонет») в роли эпитафии выступает «сонет любви на старом мавзолее», написанный от первого 
лица: звучит голос той, которая «девушкой, невестой умерла» $(1,246)$. В стихотворении говорится об «апрельском дне», в который ушла от людей девушка, не вкусившая счастья любви, но сохранившаяся, как и героиня «Легкого дыхания», в весеннем ветре, «в тишине кладбищенской аллеи», где «все говорит о счастье и весне» $(1,246)$. Как часто бывает в мире Бунина, «бессмертной грустью» об ушедшей невесте проникнут весь весенний мир, обретший в последней строке сонета «вертикаль»: «А небеса синеют вдоль аллеи» $(1,247)$.

В «Эпитафии» 1917 г. Бунин в обращении к умершей усиливает романтическую стилизацию за счет сравнений и метафор в изображении девушки:

«На земле ты была точно дивная райская птица На ветвях кипариса, среди золоченых гробниц. Юный голос звучал, как в полуденной роще цевница, И лучистые солнца сияли из черных ресниц» $(2,174)$.

Эта стилизация также акцентирована указанием на «отмеченность» героини роком, то есть создается образ идеальной красавицы, чья красота несовместима с реальностью, отсюда дидактический финал: «Красота лишь в Эдеме не знает запретных границ» $(2,174)$. Фактор адресации способствует усилению романтической оппозиции «рай / земля», возведению ее до уровня трагического, что вполне объяснимо временем написания стихотворения, датированного сентябрем 1917 г.

Ретроспективный вектор художественного мышления И. А. Бунина обусловил актуализацию жанра дружеского послания, чаще всего имеющего форму обращения к уже ушедшим людям. Это также традиционный жанр, достаточно распространенный в поэзии XIX в. (ср.: «Памяти Н. А. Добролюбова» Н. А. Некрасова, «Памяти В. А. Жуковского» Ф. И. Тютчева).

Группа текстов, объединенных категорией памяти, представляет своеобразную модификацию дружеского послания в поэзии Бунина: «Памяти М. Е. Салтыкова» (1889), «Памяти Н. И. Пирогова» (1897), «Памяти» (1906-1911), «Памяти друга» (1916), «День памяти Петра» (1925). В прозе Буниным написаны три мемориальные статьи: «Памяти Т. Г. Шевченко» (1891) по случаю 30-летия смерти одного из его любимых поэтов, 
«Памяти сильного человека (По поводу 70-летней годовщины со дня рождения И. С. Никитина - 21 сентября 1824 г.)» (1894) и «Памяти П. А. Нилуса» (1946).

Два стихотворения с «абстрактно-отвлеченными» (Е. Дмитриев) адресатами - «Памяти» (1906-1911) и «Памяти друга» (1916) - неизменно печатались во всех его собраниях и воспринимались как программные тексты. В эту группу можно включить стихотворение «День памяти Петра» (1925). Оно возвращено в корпус бунинских поэтических текстов в «Антологии зарубежной поэзии», которая была издана в Берлине в 1936 г. с вынесенными в эпиграф пушкинскими строками из «Медного всадника» как приметой конкретной адресации.

«Памяти» (1906-1911) и «Памяти друга» (1916) представляют собой своеобразный диптих. Объединенные общим адресованным сюжетом "разговора» с умершим другом, они являют собой два разных способа взаимодействия адресанта и адресата. В «Памяти» персонификация «абстрактно-отвлеченного» адресата происходит именно благодаря жанровому закону адресации - обращению в первой строке к «собеседнику» - памяти: «Ты мысль, ты сон...» $(2,23)$. Мотив сна как особой «территории» памяти не раз будет повторен в бунинских стихотворениях и прозе, достаточно вспомнить: «Зачем же воскресаешь Ты во сне, / Несрочной прелестью сияя...» $(2,191)$ и подобное воскрешение во сне Арсеньева образа его возлюбленной Лики в финале романа «Жизнь Арсеньева».

Память конкретизируется и в образе кладбища как основного визуального топоса: «Сквозь дымную метель / Бегут кресты - раскинутые руки» $(2,23)$. Визуальный образ сменяется слуховым: «Я слушаю задумчивую ель - / Певучий звон...», и следует дидактико-риторический вывод: «Все - только мысль и звуки!» $(2,23)$. Закрепленное в языке представление об ели (сосне) как о вечнозеленом дереве имплицирует мотив вечности, ощутимой, как и в рассказе «Сосны», в звуках бытия отсюда музыкальная образность в описании шума сосен («...гул сосен сдержанно и немолчно говорил и говорил о какойто вечной, величавой жизни» ${ }^{6}$. Живой, одухотворенной, мыслящей субстанцией памяти становится уже не кладбище, а весь природный мир, причем «задумчивость» ели является 
ее пейзажной приметой: «Хвойные деревья передают <...> скорее таинственное молчание, оцепенение, погруженность в себя», при этом «несменяемая зелень вызывает ассоциации хвойных деревьев с вечным покоем, глубоким сном, над которым не властно время...» [Эпштейн: 75-76].

Персонифицируемый адресат - близкий автору умерший человек - вводится в текст частым у Бунина риторическим вопросом: «То, что лежит в могиле, разве ты?» $(2,23)$, то есть истинным хранителем памяти становится воспоминание об ушедшем человеке, делающее его вечным, отсюда итоговый вывод: «Теперь ты мысль. Ты вечен» $(2,23)$.

В стихотворении «Памяти друга» (1916) адресат конкретизируется и сразу наделяется «голосом», точнее, «мыслью», выраженной прямой речью и оформленной как обращение к адресанту. Именно его умерший друг выступает в данном случае (особенно в первой части стихотворения) более активным интеллектуальным субъектом. Именно он раскрывает творческую - художническую - программу и адресата, и адресанта, то есть это своего рода «автокоммуникация» (Ю. М. Лотман) или «автоадресация» (Е. В. Дмитриев): «Как остро мы любили мир с тобою / Любовью неразгаданной, слепою!» $(2,163)$ :

\section{«И ты сказал: "Послушай, где, когда}

Я прежде жил? Я странно болен - снами,

Тоской о том, что прежде был я Бог...

О, если б вновь обнять весь мир я мог!”» $(2,163)$.

Это стихотворение с более конкретным адресатом манифестирует уже не просто память, а прапамять, пробуждающуюся в человеке в снах и творческих состояниях антиципации. Прапамять способна воссоздать, вернуть человеку утерянное им райское чувствование мира, когда он мог «быть вселенной, / Полями, морем, небом», мог соприкасаться «душой со всем живущим» $(2,163)$. Бунин не раз будет возвращаться к этим размышлениям в более поздних произведениях: «Ночь» (1925), «Жизнь Арсеньева» (1927-1930), «Освобождение Толстого» (1937).

Стихотворение «Памяти друга» вызвано известием о самоубийстве друга И. А. Бунина художника В. П. Куровского, 
с которым он путешествовал в 1900 г. по Германии и Швейцарии (см. об этом: [Двинятина, 2014b: 447]), то есть снова имплицитно заявлена тема «смерти поэта». Предметом полемики с умершим другом становится его «вольная смерть», которую автор объясняет невозможностью реализации творческой сверхзадачи - возвращения «потерянного рая», богоподобного статуса человека-творца, отсюда ассоциативно возникает образ Адама:

«И прав ли ты, не превозмогший тесной

Судьбы своей и жребия творца,

Лишенного гармонии небесной...» $(2,163)$.

В финале стихотворения звучат элегичные и одновременно «рефлексивно-скорбные» риторические вопрошания автора-адресанта: «Зачем я этот вечер вспоминаю, / Зачем ищу ничтожных слов, - не знаю» $(2,163)$. Усилившаяся накануне «гибели России» поэтологическая рефлексия Бунина проявляется во многих стихотворениях 1916 г., в частности в написанном ранее программном стихотворении «В горах» (1916), в котором также исследуется феномен прапамяти и возникает общий мотив о «ненужности» слов: «Поэзия темна, в словах невыразима» $(2,138)$.

«День памяти Петра» (1925) - уникальное для Бунина произведение, его вклад в «петербургский текст» русской словесности. Оно датировано днем смерти императора Петра 28 января (по ст. ст.). Уникально оно и в жанровом отношении: в нем два адресата - А. С. Пушкин и Петр Великий, «поэт и Царь» - творец и создатель Петербурга. В некоторых изданиях цитата из «Медного всадника» «Красуйся, град Петров и стой / Неколебимо, как Россия», начинающее стихотворение, выносилась в эпиграф (см.: [Двинятина, 2014b: 447]). Уже переживший «падение России» в 1917 г. автор вопрошает:

«Где Град Петра? И чьей рукой

Его краса, его твердыни

И алтари разорены?» $(2,195)$.

Вторая строфа, изображающая революцию, дает ответ и четкую авторскую оценку «окаянных дней» России как события метаисторического уровня, как «царства Сатаны», 
восставшего на «Божий строй и лад» и скрывшего «пучиной окаянной» «Великий и священный Град, / Петром и Пушкиным созданный».

Третья строфа заключает пушкинскую аллюзию на «послание Чаадаеву», поддержанную ритмикой:

«И все ж придет, придет пора

И воскресенья и деянья,

Прозрения и покаянья» $(2,196)$.

И ожидаемое - пушкинское «Россия вспрянет ото сна» оправдывается торжественным, одическим обращением к Родине:

«Россия! Помни же Петра.

Петр значит Камень. Сын Господний

На Камени созиждет храм

И скажет: “Лишь Петру я дам

Владычество над преисподней”» $(2,196)$.

Будущее России, по мысли автора, оправдает провиденциальное заявление Пушкина о «неколебимости» России, воплощенной в построенном на «Камени» православной веры и культуры граде Петра. Благодаря пушкинскому и евангельскому «контекстам понимания», в стихотворении «День памяти Петра» столь очевидно Буниным заявлена вера в Россию, адресованная не только ей самой, погибшей ныне, но в большей степени оторванным от родины соотечественникам. Не случайно, Бунин неоднократно публиковал это стихотворение в своих сборниках произведений, газетах, в «Антологии зарубежной поэзии», вышедшей в Берлине в 1936 г. (см.: [Двинятина, 2014b: 467]).

Вместе с тем «факторы образования жанрового значения произведения разнообразны» [Захаров: 53]. Л. Г. Кихней особо отмечает вид адресации стихотворений, в заголовках которых использованы «словоформы типа “на смерть. ..", "смерть...” или просто знаковые даты (смерти, годовщины), имплицитно выражающие скорбь об умершем. Ср.: "На смерть Князя Мещерского” Г. Р. Державина, “Смерть поэта” М. Ю. Лермонтова, “29-е января 1837” Ф. И. Тютчева» [Кихней]. При всей устойчивости этих жанровых образований в художественной 
практике XIX-XX вв., они не получили в литературной традиции канонического жанрового имени.

Сугубо бунинским видом адресованного текста эпитафийного жанра можно считать стихотворения, объединенные лирическим сюжетом посещения поэтом могилы собрата-поэта или легендарной личности: «Над могилой Надсона» (1887), «Могила поэта» (1905), «Гробница Сафии» (1903-1905), «Гробница Рахили» (1907), «Гробница» (1912), «У гробницы Виргилия» (1916). «Смерть поэта» овеществлена в данных произведениях гробницей, рождающей монологическую речь автора с диалогической установкой на общение с ушедшим предшественником.

Стихотворение «У гробницы Виргилия» создано в Неаполе, весной 1916 г. и вначале имело заглавие «У гробницы Виргилия, весной» (см.: [Двинятина, 2014b: 429]). Выбор Вергилия в качестве собеседника, конечно, не случаен: его легендарная репутация и подтверждается, и опровергается Буниным. Древнеримский поэт действительно является своего рода проводником, но не в ад, а в рай «земной жизни»:

«Знал поэт: опять весною

Будет смертному дано

Жить отрадою земною,

А кому - не все ль равно!» $(2,133)$.

Это единственный адресованный текст, где у Бунина появляется идеальный собеседник, в качестве которого выступает другой поэт - единомышленник: «Верю - знал ты, умирая, / Что твоя душа - моя» $(2,132)$.

В отличие от «Памяти друга», автор уже знает, зачем вспоминает своего предшественника: предметом их "разговора» с Вергилием, данного в двух серединных строфах стихотворения, является доказательство того, что «нет в мире разных душ» $(2,139)$ :

«...Счастлив я,

Что моя душа, Вергилий,

Не моя и не твоя» $(2,133)$.

Это знание и связывает поэта современности с поэтом древности, соединяя прошлое, настоящее и будущее и укореняя 
их в вечности. Примечательно, что Бунин, находясь у могилы Вергилия, вспоминал Пушкина, о чем автор «Памяти друга» пишет в маленькой заметке «Думая о Пушкине»: «Вот, например, прекрасный весенний день. А мы под Неаполем, на гробнице Вергилия, и почему-то я вспоминаю Пушкина, душа полна его веянием - и я пишу: “Дикий лавр, и плющ, и розы <...>”»". Позже, в дневниковой записи 1940 г., Бунин цитирует признание великого поэта: «Пушкин незадолго до смерти писал: “Моя душа расширилась: я чувствую, что могу творить"»".

Именно диалогичная форма лирического размышления о художнической, поэтической общности, о «душе поэта» как особой эстетической категории позволила Бунину в адресованных текстах заявить категорию прапамяти и осознать ее как основную особенность творческой личности, как метафизическую предпосылку бессмертия поэта.

Итак, в адресованных поэтических жанрах в творчестве Бунина рождается новый принцип систематизации текстов не столько по жанровому признаку, сколько по адресату и тематическому принципу. Этим обусловлено появление скрытых циклов (надсоновский, бальмонтовский). Сами стихотворения-посвящения почти не содержат цитат, аллюзий и иных знаков адресата, поэтому снятие посвящений в заголовочном комплексе лишают стихотворения всяких примет адресованного жанра.

И. А. Бунин явно тяготеет к вневременным и отвлеченноабстрактным адресатам, поэтому убирает из собраний сочинений почти все именные стихотворения-посвящения. В оставшихся текстах в заголовках посвящений чаще всего присутствуют скобки, в которые заключена фамилия или инициалы адресатов, что можно трактовать как авторский знак их условности. Вместе с тем вынесенная в заголовок цитата, памятная дата, имя адресата, первые строки, выполняющие функцию эпиграфа, - своеобразные приметы посвящений в поэзии И. А. Бунина.

Основным структурирующим началом адресации в поэзии Бунина становится память, лишенная сугубо биографических примет, но ориентированная на религиозный и культурный 
опыт «аудитории». Поэт активно использует способы диалогизма, которые содержат в себе такие традиционные адресованные жанры, как эпитафия, псалом, притча, эпиталама, что влечет за собой панегирический тип адресации. В поэзии Бунина, как и у его современников, появляется особая жанровая модификация - эпитафическое дружеское послание. При этом особенностью стихотворений Бунина становится преобразование парадигмы «смерть поэта» в понятие «могила / гробница поэта» / легендарной личности.

Вещественные знаки памяти - гробница, надпись, природные явления, - важные, но менее значимые, чем прапамять. Именно адресация позволяет автору установить невербальный диалог с предшественниками, поэтому такие виды диалога чаще всего носят характер «автоадресации». Тем самым И. А. Бунин вносит свой вклад в разработку новых художественных коммуникативных стратегий, формирующихся в поэзии XX в.

\section{Примечания}

1 Ф. Д. Батюшков пишет: «Бунин занимает серединное место между обоими течениями (футуризмом и символизмом. - О. Б.): он не новатор, но во многом нов, он не “модернист", но во многом “модерн". Он в то же время преемник и последователь традиционной поэзии классической у нас школы, по заветам Пушкина» [Батюшков: 402]. Об этом же пишет И. Ф. Анненский в «Рецензии на 1-5 тома сочинений Бунина 1904-1909 гг.»: «Он в меру модернист, при этом не чужд классицизма» [Анненский: 301].

2 Бунин И. Стихотворения: в 2 т. / вступ. ст., сост., подгот. текста, примеч. Т. М. Двинятиной. СПб.: Издательство Пушкинского Дома; Вита Нова, 2014. (Серия «Новая библиотека поэта»). Далее ссылки на это издание приводятся в тексте статьи с указанием тома и страницы в круглых скобках.

3 См., напр.: [Бердникова, 2011], [Двинятина, 2011].

4 В 1 томе шеститомного собрания сочинений стихотворение «Матери» датировалось 1906-1911 гг. (Бунин И. А. Собр. соч.: в 6 т. М.: Худож. лит., 1987. Т. 1. С. 258). В двухтомном собрании стихотворений (СПб., 2014) датировка уточнена: 1901; 1910 (1, 244-245).

5 Бунин И. А. Письма 1905-1919 годов / под общ. ред. О. Н. Михайлова. М.: ИЛМИ РАН, 2007. С. 719.

6 Бунин И. А. Собр. соч.: в 6 т. М., 1987. Т. 2. С. 195. 
7 Следует отметить, что и в прозаических текстах адресация структурирует текст; это проявляется в свойственных адресованным жанрам побудительных формах: «Всмотритесь в его лицо на портрете...», «Откройте его книгу...». См. ст. «Памяти сильного человека» И. А. Бунина в: Бунин И. А. Собр. соч.: в 6 т. М., 1988. Т. 6. С. 587-592.

8 Там же. С. 620.

9 Там же. С. 476.

\section{Список литературы}

1. Айхенвальд Ю. Силуэты русских писателей. - М.: Республика, 1994. $591 \mathrm{c}$.

2. Анненский И. Ф. <Рецензия на 1-5 тома сочинений Бунина 19041909 гг.> // Иван Бунин: Pro et contra. Личность и творчество Ивана Бунина в оценке русских и зарубежных мыслителей и исследователей. Антология. - СПб.: Изд-во РХГИ, 2001. - С. 300-303.

3. Батюшков Ф. Д. Ив. А. Бунин // Русская литература XX века. 1890-1910 / под ред. проф. С. А. Венгерова. - М.: Республика, 2004. - С. 397-410.

4. Бердникова О. А. «Так сладок сердцу Божий мир»: творчество И. А. Бунина в контексте христианской духовной традиции. - Воронеж: Изд-во им. Е. А. Болховитинова, 2009. - 272 с.

5. Бердникова О. А. Адресация в поэтическом творчестве И. А. Бунина // Метафизика И. Бунина: межвуз. сб. науч. тр. - Воронеж: Наука-ЮНИПРЕСС, 2011. - Вып. 2. - С. 135-147.

6. Брюсов В. Я. Ив. Бунин // Иван Бунин: Pro et contra. Личность и творчество Ивана Бунина в оценке русских и зарубежных мыслителей и исследователей. Антология. - СПб.: Изд-во РХГИ, 2001. - С. 266-267.

7. Вейдле В. В. На смерть И. А. Бунина // Иван Бунин: Pro et contra. Личность и творчество Ивана Бунина в оценке русских и зарубежных мыслителей и исследователей. Антология. - СПб.: Изд-во РХГИ, 2001. - C. 419-432.

8. Двинятина Т. М. Бунин на мотив: О статусе переводов в ранней лирике И. А. Бунина // Метафизика И. А. Бунина: межвуз. сб. науч. тр. - Воронеж: Наука-ЮНИПРЕСС, 2011. - Вып. 2. - С. 148-167.

9. Двинятина Т. М. Примечания // Бунин И. Стихотворения: в 2 т. - СПб.: Изд-во Пушкинского Дома; Вита Нова, 2014. - Т. 1. - С. 439-533. (Серия «Новая библиотека поэта») (a)

10. Двинятина Т. М. Примечания // Бунин Иван. Стихотворения: в 2 т. СПб.: Изд-во Пушкинского Дома; Вита Нова, 2014. - Т. 2. - С. 341-492. (Серия «Новая библиотека поэта») (b)

11. Дмитриев Е. В. Фактор адресации в русской поэзии: от классицизма до футуризма. - М.: Изд-во МНЭПУ, 2003. - 287 с.

12. Захаров В. Н. Проблемы исторической поэтики: этнологические аспекты. - М.: Индрик, 2012. - 264 с. 
13. Кихней Л. Г. Жанровое своеобразие «эпитафической» лирики Ахматовой // Анна Ахматова: эпоха, судьба, творчество: Крымский Ахматовский науч. сб. - Вып. 3. - Симферополь: Крымский Архив, 2005. - С. 33-46 [Электронный ресурc]. - URL: http://ahmatova.niv. ru/ahmatova/kritika/kihnej-zhanrovoe-svoeobrazie-epitaficheskoj-liriki. htm (28.03.2019).

14. Круглова Т. С. Адресованная лирика русского модернизма: поэтологический аспект. - М.: Изд-во ИМПЭ им. А. С. Грибоедова, 2013. - 337 с.

15. Куприяновский П. В. Заметки к теме «И. Бунин и К. Бальмонт» // И. А. Бунин в диалоге эпох: межвуз. сб. науч. тр., посвященный творчеству И. А. Бунина. - Воронеж: ВГУ, 2002. - С. 48-55.

16. Морозов С. Н. Периодизация творчества И. А. Бунина // Метафизика И. А. Бунина: межвуз. сб. науч. тр. - Воронеж: НАУКА-ЮНИПРЕСС, 2018. - Вып. 4. - С. 7-14.

17. Тюпа В. Аналитика художественного (введение в литературоведческий анализ). - М.: Лабиринт, РГГУ, 2001. - 189 с.

18. Эпштейн М. «Природа, мир, тайник вселенной». Система пейзажных образов в русской поэзии. - М.: Высшая школа, 1990. - 303 с.

Olga A. Berdnikova

Voronezh State University

(Voronezh, Russian Federation)

olberd@mail.ru

\title{
The Poetics of the Addressed Genres in the Works of I. A. Bunin
}

\begin{abstract}
The article is dedicated to the study of the addressing as a communicative artistic phenomenon in the poetic works of I. A. Bunin, the revealing of genre, thematic and stylistic features of the addressing. In his poetry Bunin keeps on following the classical tradition and the preservation of the addressed poems in their genre certainty provided that the "timeless addressing" dominates. The addressing is found in a title complex and the genre of works. In the works of Bunin the Epitaph and Epithalamius maintain a genre shaping function of the addressed genres. The most modified forms are related to the genres of dedications and Epistles. The tendency to the cyclization inherent to the epoch leads to the appearance in Bunin's poetry of "hidden" personalized cycles (Nadson, Balmont). However, the name of an addressee is the basic and unique unifying principle: the poems-dedication hardly contain citations, allusions or other signs of the addressee. So, the removal of dedications deprives the poem of any distinctive marks of an addressed genre. The most frequent addressed genres are those grouped by the theme of memory and the paradigm of "the death of the poet", transformed by Bunin into the concept of "tomb / tomb of the poet" as a legendary figure. The special genre of an epithaphical friendly message appears that represent the panegyrical type of the addressing and allows the poet to
\end{abstract}


comprehend the category of "ancestor memory". The dialogization of the text often has the character of "auto-addressing". The least represented is an ironic addressing aimed at debates with the modernist aesthetics dominant in poetry. Bunin contributed to the development of new artistic communicative strategies that were formed in the poetry of the twentieth century.

Keywords: Bunin, poetry, addressed genres, "hidden" personalized cycles, paradigm of memory, epitaphic message, panegyric type of the addressing, new artistic communicative strategies

About the author: Berdnikova Olga A. - Doctor of Philology, Professor of the Department of Russian Literature of 20-21th Centuries, Theory of Literature and Folklore, Voronezh State University (pl. Universitetskaya 1, Voronezh, 139418, Russian Federation)

Received: April 19, 2019

Date of publication: October 18, 2019

For citation: Berdnikova O. A. The Poetics of the Addressed Genres in the Works of I. A. Bunin. In: Problemy istoricheskoy poetiki [The Problems of Historical Poetics], 2019, vol. 17, no. 4, pp. 215-241. DOI: 10.15393/j9.art.2019.6442 (In Russ.)

\section{References}

1. Aykhenval'd Yu. Siluety russkikh pisateley [The Silhouettes of Russian Writers]. Moscow, Respublika Publ., 1994. 591 p. (In Russ.)

2. Annenskiy I. F. $<$ Reviews of the 1st-5th Volumes of Bunin's Writings Dated Back to 1904-1909>. In: Ivan Bunin: Pro et contra. Lichnost' i tvorchestvo Ivana Bunina v otsenke russkikh i zarubezhnykh mysliteley $i$ issledovateley. Antologiya [Ivan Bunin: Pro et contra. Personality and Works of Ivan Bunin in the Appreciation of Russian and Foreign Thinkers and Researchers. Anthology]. St. Petersburg, Russian Christian Humanitarian Institute Publ., 2001, pp. 300-303. (In Russ.)

3. Batyushkov F. D. Iv. A. Bunin. In: Russkaya literatura XX veka. 1890-1910 [Russian Literature of the 20th Century. 1890-1910]. Moscow, Respublika Publ., 2004, pp. 397-410. (In Russ.)

4. Berdnikova O. A. «Tak sladok serdtsu Bozhiy mir»: tvorchestvo I. A. Bunina $v$ kontekste khristianskoy dukhovnoy traditsii ["The God's World is so Sweet to the Heart": I. A. Bunin's Works in the Context of the Christian Spiritual Tradition]. Voronezh, Izdatel'stvo imeni E. A. Bolkhovitinova Publ., 2009. 272 p. (In Russ.)

5. Berdnikova O. A. The Addressing in the Poetic Works of I. A. Bunin. In: Metafizika I. Bunina: Mezhvuzovskiy sbornik nauchnykh trudov [I. Bunin's Metaphysics: Interuniversity Collection of Scientific Works]. Voronezh, ScienceUNIPRESS Publ., 2011, issue 2, pp. 135-147. (In Russ.)

6. Bryusov V. Ya. Ivan Bunin. In: Ivan Bunin: Pro et contra. Lichnost' i tvorchestvo Ivana Bunina $v$ otsenke russkikh $i$ zarubezhnykh mysliteley $i$ issledovateley. Antologiya [Ivan Bunin: Pro et contra. Personality and Works of Ivan 
Bunin in the Appreciation of Russian and Foreign Thinkers and Researchers. Anthology]. St. Petersburg, Russian Christian Humanitarian Institute Publ., 2001, pp. 266-267. (In Russ.)

7. Veydle V. V. On the Death of I. A. Bunin. In: Ivan Bunin: Pro et contra. Lichnost' $i$ tvorchestvo Ivana Bunina $v$ otsenke russkikh $i$ zarubezhnykh mysliteley i issledovateley. Antologiya [Ivan Bunin: Pro et contra. Personality and Works of Ivan Bunin in the Appreciation of Russian and Foreign Thinkers and Researchers. Anthology]. St. Petersburg, Russian Christian Humanitarian Institute Publ., 2001, pp. 419-432. (In Russ.)

8. Dvinyatina T. M. Bunin About the Motif: On the Status of Translation in Early Lyrics of Ivan Bunin. In: Metafizika I. A. Bunina: mezhvuzovskiy sbornik nauchnykh trudov [I. A. Bunin's Metaphysics: Interuniversity Collection of Scientific Papers]. Voronezh, Science-UNIPRESS Press, 2011, issue 2, pp. 148-167. (In Russ.)

9. Dvinyatina T. M. Notes. In: Bunin I. Poemy: $v 2$ tomakh [Bunin I. Poems: in 2 Vols]. St. Petersburg, Pushkin Publishing House; Vita Nova Publ., 2014, vol. 1, pp. 439-533. (Ser. "New Library of the Poet") (a) (In Russ.)

10. Dvinyatina T. M. Notes. In: Bunin I. Poemy: $v 2$ tomakh [Bunin I. Poems: in 2 Vols]. St. Petersburg, Pushkin Publishing House; Vita Nova Publ., 2014, vol. 2, pp. 341-492. (Ser. "New Library of the Poet") (b) (In Russ.)

11. Dmitriev E. V. Faktor adresatsii v russkoy poezii: ot klassitsizma do futurizma [An Addressing Factor in Russian Poetry: from Classicism to Futurism]. Moscow, International Independent Ecological-Political University Publ., 2003. 287 p. (In Russ.)

12.Zakharov V. N. Problemy istoricheskoy poetiki: etnologicheskie aspekty [The Problems of Historical Poetics: Ethnological Aspects]. Moscow, Indrik Publ., 2012. 264 p. (In Russ.)

13. Kikhney L. G. The Genre Originality of the "Epitaphic" Lyrics of Akhmatova. In: Anna Akhmatova: epokha, sud'ba, tvorchestvo: Krymskiy Akhmatovskiy nauchnyy sbornik [Anna Akhmatova: Epoch, Destiny, Creativity: Akhmatova Crimean Scientific Digest]. Simferopol, Krymskiy arkhiv Publ., 2005, issue 3, pp. 33-46. Available at: http://ahmatova.niv.ru/ahmatova/ kritika/kihnej-zhanrovoe-svoeobrazie-epitaficheskoj-liriki.htm (accessed on March 28, 2019). (In Russ.)

14. Kruglova T. S. Adresovannaya lirika russkogo modernizma: poetologicheskiy aspekt [The Addressed Lyrics of Russian Modernism: A Poetological Aspect]. Moscow, A. S. Griboedov Institute of International Law and Economics Publ., 2013. 337 p. (In Russ.)

15. Kupriyanovskiy P. V. Notes on the Subject "I. Bunin and K. Balmont". In: I. A. Bunin v dialoge epokh: mezhvuzovskiy sbornik nauchnykh trudov, posvyashchennyy tvorchestvu I. A. Bunina [I. A. Bunin in the Dialogue of Epochs: Interuniversity Collection of Scientific Works Dedicated to the Works of I. A. Bunin]. Voronezh, Voronezh State University Publ., 2002, pp. 48-55. (In Russ.) 
16. Morozov S. N. The Periodization of the Works of I. A. Bunin. In: Metafizika I. A. Bunina: mezhvuzovskiy sbornik nauchnykh trudov [The Metaphysics of I. A. Bunin: Interuniversity Collection of Scientific Works]. Voronezh, NAUKA-YUNIPRESS Publ., 2018, issue 4, pp. 7-14. (In Russ.)

17. Tyupa V. Analitika khudozhestvennogo (vvedenie v literaturovedcheskiy analiz) [The Analytics of the Artistic (Introduction to a Literary Analysis)]. Moscow, Labirint Publ., Russian State University for the Humanities Publ., 2001. 189 p. (In Russ.)

18. Epshteyn M. «Priroda, mir, taynik vselennoy». Sistema peyzazhnykh obrazov $v$ russkoy poezii ["Nature, World, Hiding Place of the Universe". The System of Landscape Images in Russian Poetry]. Moscow, Vysshaya shkola Publ., 1990. 303 p. (In Russ.) 